\title{
Mateusz WiśnIEWSKI
}

Uniwersytet Mikołaja Kopernika w Toruniu

\section{PRAWNOKARNE ASPEKTY WYŁUDZENIA DOTACJI UNII EUROPEJSKIEJ}

\section{WPROWADZENIE}

Wstąpienie Polski do UE spowodowało, że grupy przestępcze zyskały nowy obszar dla swojej działalności w postaci możliwości wyłudzania dotacji z funduszy tej organizacji. Nie ulega przy tym wątpliwości, że obecnie przestępcy skupiają się na popełnianiu przestępstw gospodarczych, które przynoszą znaczne korzyści majątkowe, a przy tym są trudne do wykrycia. Z przeprowadzonych badań wynika jednoznacznie, że jednym z istotnych obszarów działalności przy tzw. przestępstwach „białych kołnierzyków” jest bezprawne uzyskanie dotacji pochodzącej ze środków unijnych ${ }^{1}$. W takim przypadku za konieczne należy uznać przedstawienie najpopularniejszych metod, których zastosowanie może skutkować wyłudzeniem dotacji z funduszy Unii Europejskiej. Ponadto kwestia odpowiedzialności karnej za analizowane zachowanie nie została uregulowana jednym przepisem karnym, co spowodowało, że problematyka kwalifikacji prawnej czynu polegającego na bezprawnym uzyskaniu wsparcia unijnego pozostaje

\footnotetext{
1 Komunikat Prokuratury Generalnej, por. http://pk.gov.pl/aktualnosci-prokuratury-krajowej/prokuratura-generalna-o-przestepstwach-na-szkode-finansowych-interesow-unii-europejskiej-2-693,subakcja,print.html (dostęp 10 stycznia 2017 r.).
} 
zagadnieniem, które budzi szereg wątpliwości. Dlatego też celem niniejszego opracowania jest przedstawienie implikacji wynikających z obecnego rozproszenia norm przewidujących karalność za wyłudzenie dotacji oraz udzielenie odpowiedzi na pytanie, czy utrzymywanie obecnego stanu prawnego jest nadal uzasadnione.

\section{MODUS OPERANDI}

Z dostępnych danych statystycznych wynika, że ok. 87\% spraw dotyczy prób wyłudzenia środków finansowych z Agencji Restrukturyzacji i Modernizacji Rolnictwa. W ok. 13\% spraw chodzi natomiast o wyłudzanie subwencji UE rozdzielanych w ramach różnych programów operacyjnych ${ }^{2}$. Już w tym miejscu warto zaznaczyć, że określenie: „wyłudzenie dotacji na szkodę UE” jest pewnym skrótem myślowym, albowiem pokrzywdzonym przestępstwem jest krajowy organ, który dysponuje otrzymanymi środkami z funduszy UE. Mechanizm udzielania wsparcia unijnego zakłada bowiem udział pośredniczącej instytucji rządowej, której zadaniem jest podział środków pochodzących z budżetu Unii.

Grupy lub związki przestępcze posługują się różnymi metodami prowadzącymi do bezprawnego uzyskania wsparcia unijnego. Jednym ze sposobów jest stworzenie sieci fikcyjnych podmiotów gospodarczych, które ubiegają się o dofinansowanie z funduszu zarządzającego środkami unijnymi. Następnie uzyskane środki trafiają do rąk prezesów fikcyjnych przedsiębiorstw, którzy tworzą dokumentację uwiarygadniającą wykorzystanie pozyskanych środków pieniężnych.

Odmianą tej metody jest nielegalne pozyskanie dotacji przy udziale co najmniej jednej osoby, która jest odpowiedzialna za ocenę wniosków o dofinansowanie konkretnych projektów. Dotowane ze środków UE projekty nie są realizowane, ale jest tworzona dokumentacja, która ma potwierdzić wykonanie takiego projektu. Niekiedy kierujący takim procederem włączają do niego osoby trzecie, które mają dodatkowo

2 Ibidem. 
uwiarygodnić jego legalność w ten sposób, że stwierdzają np. własnym podpisem fakt udziału w szkoleniu.

Jednym ze sposobów uzyskania dotacji jest wprowadzenie instytucji dysponującej środkami unijnymi w błąd w ten sposób, że podmiot ubiegający się o dotację oświadcza, iż spełnia wszystkie wymagania. Przykładowo, osoba zarządzająca przedsiębiorstwem oświadcza, że nie będzie przy realizacji dotowanego projektu współpracować z firmą, której właścicielem jest osoba dla niej najbliższa lub powiązana kapitałowo, co jednak przy realizacji projektu ma miejsce. W ten sposób firma powiązana kapitałowo uzyskuje możliwość wykonywania odpłatnych usług na rzecz podmiotu, który uzyskał dotację.

Wykonywanie fikcyjnych usług doradczych to kolejny sposób na wyłudzenie środków będących w dyspozycji Agencji Restrukturyzacji i Modernizacji Rolnictwa. Mechanizm działania polega na tym, że firmy posiadające akredytację Ministerstwa Rolnictwa i Rozwoju Wsi przeprowadzają fikcyjne audyty gospodarstw rolnych. Nierzetelne dokumenty są przekazywane do Agencji Restrukturyzacji i Modernizacji Rolnictwa. $\mathrm{Na}$ ich podstawie agencja wypłaca wynagrodzenie za wykonanie usługi doradczej w wysokości 80\% jej wartości. Pozostałe 20\% stanowi koszt rolnika, u którego audyt został przeprowadzony. Co prawda audyty gospodarstw rolnych nie są obowiązkowe, jednak posiadanie zaświadczenia o jego przeprowadzeniu przez licencjonowaną firmę to wiarygodna ocena gospodarstwa pod względem zgodności z wymogami UE. Audyt pomaga rolnikowi ubiegać się o dopłaty bezpośrednie, dotacje na modernizację gospodarstwa albo unijną pomoc finansową na zakup sprzętu rolniczego ${ }^{3}$.

3 W celu ograniczenia tego procederu zmieniono rozporządzenie Ministra Rolnictwa i Rozwoju Wsi w sprawie szczegółowych warunków i trybu przyznawania pomocy finansowej w ramach działania „korzystanie z usług doradczych przez rolników i posiadaczy lasów” objętego programem rozwoju obszarów wiejskich na lata 2007-2013 (Dz.U. z 2013 r. poz. 689). Wprowadzona zmiana polegała na tym, że ubiegający się o udzielenie dofinansowania musiał przedstawić dowód wpłaty na rachunek bankowy biura doradczego, co miało potwierdzać faktyczne wykonanie audytu. 


\section{KWALifikaCJA PRAWNA CZYNU}

Sporo kontrowersji budzi kwalifikacja prawna czynu polegającego na wyłudzeniu dotacji ze środków UE. Powyższe stwierdzenie wynika z tego, że do omawianej problematyki nawiązuje nie tylko art. 297 $\$ 1$ k.k., ale również art. $286 \$ 1$ k.k. i art. $82 \$ 1$ k.k.s. Już w tym miejscu podkreślić należy, że w doktrynie sformułowano postulat de lege ferenda, który opowiada się za koniecznością uchylenia art. $82 \$ 1$ k.k.s. Autor uzasadnia swój pogląd tym, że art. $82 \$ 1$ k.k.s. w zasadniczej części pokrywa się z treścią art. $297 \$ 1 \mathrm{k} . \mathrm{k} .{ }^{4} \mathrm{~W}$ celu pełnego przedstawienia problemów, które wyłaniają się w związku z udzielaniem oraz późniejszym wykorzystywaniem dotacji unijnych, rozważania jurydyczne zostaną uzupełnione o art. $286 \$ 1$ k.k., co umożliwi dokonanie pełnej oceny obecnych uregulowań.

3.1. Analiza porównawcza art. $297 \$ 1$ k.k. i art. $82 \$ 1$ k.k.s.

W pierwszej kolejności przedstawione zostanie porównanie art. 297 $\$ 1$ k.k. oraz art. $82 \$ 1$ k.k.s., co pozwoli ocenić, czy wskazany powyżej pogląd zasługuje na akceptację. W tym celu należy odnieść się do przedmiotu ochrony, podmiotu przestępstwa, strony podmiotowej oraz przedmiotowej tych czynów, co być może pozwoli na dostrzeżenie pewnych różnic zachodzących między porównywanymi normami.

Przechodząc do określenia przedmiotu ochrony porównywanych norm należy dojść do wniosku, że art. 297 k.k. chroni prawidłowe funkcjonowanie wymienionych w $\$ 1$ instrumentów finansowych, a zatem również dotacji unijnej ${ }^{5}$. Z kolei przedmiotem ochrony art. $82 \$ 1$ k.k.s. są „środki finansowe pochodzące $z$ budżetu państwa lub budżetów jednostek samorządu terytorialnego, a przeznaczone na dotacje lub

4 G. ŁaBudA, [w:] Kodeks karny skarbowy. Komentarz, red. P. KARDAs, G. ŁaBUDA, T. RAzowski, Warszawa 2012, s. 762.

M. GaŁązKa, [w:] Kodeks karny. Komentarz, red. A. GrZeśKowiaK, K. WiaK, Warszawa 2017, s. 1315; I. Zgoliński, [w:] Kodeks karny. Komentarz, red. V. KonARSKA-Wrzosek, Warszawa 2016, s. 1249-1250. 
subwencje"6. Z powyższego przedstawienia wynika, że obydwie normy chronią tożsame dobra prawne.

Ponadto omawiane czyny mają charakter formalny. Sprawca popełnia bowiem delikt skarbowy z momentem narażenia finansów publicznych na uszczuplenie, co oczywiście oznacza, że zaistnienie uszczerbku jest wysoce prawdopodobne, choć wcale nie musi wystąpić. Z kolei przestępstwo objęte dyspozycją art. $297 \$ 1$ k.k. jest dokonane $\mathrm{z}$ chwilą przedłożenia nierzetelnych lub poświadczających nieprawdę dokumentów, albo nierzetelnych oświadczeń. Wydaje się, że moment dokonania porównywanych występków jest tożsamy. Takie twierdzenie motywowane jest tym, że sprawca, który przedkłada nierzetelne lub poświadczające nieprawdę dokumenty, już w tym momencie naraża budżet Skarbu Państwa na wypłatę nienależnej dotacji.

Podkreślić należy, że zarówno czyn z art. $297 \$ 1$ k.k., jak i art. 82 $\$ 1$ k.k.s. jest popełniony na szkodę krajowej instytucji, która udzieliła dotacji. Z całą pewnością treść art. $113 \$ 2$ pkt 1 k.k.s., która wyłącza możliwość zastosowania w postępowaniu karnym skarbowym norm k.p.k. dotyczących pokrzywdzonego, nie stanowi przeszkody dla takiego stwierdzenia. Brak możliwości zastosowania przepisów k.p.k., które odnoszą się do pokrzywdzonego nie świadczy o tym, że w postępowaniu karnoskarbowym nie występuje szkoda oraz pokrzywdzony ${ }^{7}$. Wskazane wyłączenie stanowi naturalną konsekwencję tego, że najczęściej to organ prowadzący postępowanie karnoskarbowe jest również pokrzywdzonym. W tym miejscu warto odnotować, że w orzecznictwie sądowym zakwestionowano możliwość uznania krajowej instytucji za pokrzywdzonego przestępstwem $\mathrm{z}$ art. $297 \$ 1 \mathrm{k} . \mathrm{k}$. Zdaniem SN taka możliwość nie istnieje, ponieważ omawiany występek ma bezskutkowy charakter ${ }^{8}$. Wskazany judykat został jednak poddany słusznej krytyce. Zwrócić bowiem należy uwagę, że z chwilą przedłożenia podrobionych dokumentów doszło do bezpośredniego zagrożenia zindywidualizowanego

\footnotetext{
A. Piaseczny, Kodeks karny skarbowy. Komentarz, «Legalis».

Szerzej na ten temat: L. WILK, Zasada priorytetu egzekucji nad represja w prawie karnym skarbowym, «Prokuratura i Prawo» 7-8/2012, s. 8.

Wyrok SN z 5 maja 2011 r., IV KK 57/11, «Prokuratura i Prawo. Dodatek Orzecznictwo» 11/2011, s. 8 .
} 
dobra w postaci dotacji unijnej ${ }^{9}$. Następstwem takiego ustalenia jest uznanie krajowego organu dysponującego środkami unijnymi za pokrzywdzonego w rozumieniu art. $49 \$ 1$ k.p.k.

Analizowane normy nie wykazują jednak podobieństwa w zakresie strony podmiotowej. Ze względu na to, że art. $297 \$ 1$ k.k. wymaga działania „w celu”, możliwe jest popełnienie tego występku jedynie umyślnie z zamiarem bezpośrednim kierunkowym ${ }^{10}$. Sprawca musi bowiem wiedzieć, że przedkłada fałszywe lub poświadczające nieprawdę dokumenty w celu uzyskania wsparcia pochodzącego ze środków unijnych. Podobne zastrzeżenie nie występuje na gruncie art. $82 \$ 1$ k.k.s., co prowadzi do wniosku, że zachowanie opisane w tym przepisie może przybrać również formę zamiaru ewentualnego ${ }^{11}$. Wynika $z$ tego, że obecne brzmienie art. $82 \$ 1$ k.k.s. pozwala na objęcie penalizacją zachowania polegającego na godzeniu się z bezprawnym uzyskaniem dotacji.

Podnieść należy, że różnice przebiegają również na płaszczyźnie strony przedmiotowej. O ile art. $297 \$ 1 \mathrm{k} . \mathrm{k}$. wymaga, aby sprawca posłużył się podrobionym, przerobionym, poświadczającym nieprawdę albo nierzetelnym dokumentem albo nierzetelnym pisemnym oświadczeniem dotyczącym okoliczności o istotnym znaczeniu, to jednak art. $82 \$ 1$ k.k.s. nie zawiera takiego zastrzeżenia. Wynika $z$ tego, że popełnienie występku skarbowego możliwe jest w sytuacji, gdy sprawca nie posługuje się środkami wymienionymi w art. $297 \$ 1$ k.k.

W tym miejscu warto jednak zwrócić uwagę, że art. $82 \$ 1$ k.k.s., w przeciwieństwie do art. $297 \$ 1$ k.k., przewiduje karalność za wykorzystanie dotacji niezgodnie z jej przeznaczeniem. Wobec tego można zaryzykować stwierdzenie, że za występek z art. $82 \$ 1$ k.k.s. może

9 A. Michalska-Warias, [w:] Kodeks karny. Część szczególna, II, red. M. KróLikowski, R. ZAwŁocki, Warszawa 2013, s. 916; S. ŻóŁtek, Szkoda i pokrzywdzony przestępstwem oszustwa kredytowego, «Monitor Prawniczy» 21/2011, s. 1175.

10 Wyrok SN z 30 sierpnia 2000 r., sygn. akt V KKN 267/00, «Orzecznictwo Sądu Najwyższego Izba Karna i Izba Wojskowa» 9-10/2000; postanowienie SN z 25 lutego 2002 r., sygn. akt I KZP 1/02, «Orzecznictwo Sądu Najwyższego Izba Karna i Izba Wojskowa» 5-6/2002.

11 Por. W. Kotowski, B. KurzęPA, Kodeks karny skarbowy. Komentarz, Warszawa 2006, s. 298; T. GrzegorCzy K, Kodeks karny skarbowy. Komentarz, Warszawa 2009, s. 387. 
odpowiadać podmiot, który uzyskał dotację na podstawie rzetelnej oraz prawdziwej dokumentacji pod warunkiem, że w toku realizacji określonego przedsięwzięcia środki pochodzące z dotacji zostaną wykorzystane niezgodnie z jej przeznaczeniem. Należy bowiem podkreślić, że z treści obydwu przepisów wynika konieczność dokonania odmiennej oceny zachowania sprawcy, który powziął zamiar przeznaczenia dotacji niezgodnie z jej przeznaczeniem dopiero po jej uzyskaniu. Wydaje się jednak, że należy wykluczyć możliwość poprzestania jedynie na przedstawieniu zarzutu $\mathrm{z}$ art. $82 \$ 1$ k.k.s. sprawcy, który w momencie wystąpienia z wnioskiem o udzielenie dotacji miał zamiar przeznaczyć środki z niej pochodzące na inne cele. Przede wszystkim chęć wykorzystania dotacji niezgodnie z jej przeznaczeniem już na etapie składania wniosku wyklucza możliwość uznania, że sprawca przedłożył rzetelną dokumentację. W takim przypadku sprawca, co najmniej, przedkłada fałszywe oświadczenie co do tego, że dotacja zostanie wykorzystana zgodnie z celem, co z kolei aktualizuje kwestię odpowiedzialności karnej za czyn $z$ art. $297 \$ 1$ k.k.

Ze względu na to, że podmiotem przestępstwa skarbowego określonego $\mathrm{w}$ art. $82 \$ 1$ k.k.s. może być również pracownik organu państwowego lub samorządowego decydującego o przyznaniu dotacji lub subwencji, można przyjąć, że za delikt skarbowy (niezależnie od odpowiedzialności z art. $231 \S 1-3$ k.k.) może odpowiadać np. urzędnik, który nie zweryfikował należycie dokumentacji przedłożonej przez wnioskującego i godził się z tym, że wypłata nienależnej dotacji, bądź subwencji narazi Skarb Państwa na straty. Jeżeli funkcjonariusz publiczny nie będzie działał z zamiarem bezpośrednim kierunkowym, to wówczas pozostaje jedynie możliwość przedstawienia mu zarzutu $\mathrm{z}$ art. $82 \S 1$ k.k.s. i ewentualnie $\mathrm{z}$ art. $231 \S 1-3$ k.k.

Prima facie tylko osoba, która przedłożyła nierzetelne dokumenty może odpowiadać karnie za popełnienie przestępstwa $\mathrm{z}$ art. 297 \$1 k.k. Tak jednak nie jest. Z całą pewnością urzędnik, który wszedł w porozumienie z wnioskującym i działa z zamiarem bezpośrednim o szczególnym zabarwieniu, chcąc, aby określony podmiot prowadzący działalność gospodarczą uzyskał nienależną dotację, może zostać uznany za współsprawcę. Tej oceny nie zmienia fakt, że to nie urzędnik przedłożył 
podrobione, przerobione lub poświadczające nieprawdę dokumenty. Takie twierdzenie wynika z tego, że nie każdy ze współsprawców musi osobiście realizować wszystkie znamiona przestępstwa, każdy musi jednak podejmować takie działania, które łącznie $\mathrm{z}$ działaniem innego uczestnika porozumienia zmierzają do dokonania przestępstwa. Wystarczające jest bowiem ustalenie, że zachowanie takiego współsprawcy miało istotne znaczenie dla zaistnienia skutku w postaci wyłudzenia dotacji.

3.2. Problematyka art. $286 \$ 1$ k.k. jako normy penalizującej zachowanie polegające na bezprawnym uzyskaniu dotacji

W celu pełnego przedstawienia problemów wyłaniających się z kwalifikacji prawnej czynu polegającego na wyłudzeniu dotacji unijnej, poczynione powyżej rozważania jurydyczne muszą zostać uzupełnione o kwestię odpowiedzialności karnej za przestępstwo oszustwa (art. 286 $\$ 1$ k.k.). Analizując znamiona strony przedmiotowej czynu objętego dyspozycją art. $286 \$ 1$ k.k., można odnieść pozornie wrażenie, że każde zachowanie polegające na bezprawnym uzyskaniu dotacji z funduszy Unii Europejskiej będzie realizować znamiona występku oszustwa. Sprawca działa $\mathrm{z}$ góry powziętym zamiarem, a jego celem jest chęć uzyskania określonej korzyści majątkowej. Przy czym wprowadza podmiot dysponujący środkami unijnymi w błąd chociażby co do zamiaru wywiązania się ze zobowiązań, które wynikają z udzielonego wsparcia finansowego ${ }^{12}$. Właśnie $\mathrm{w}$ tym ostatnim elemencie, tj. wprowadzeniu określonej instytucji w błąd dostrzegalna jest zasadnicza różnica pomiędzy art. $286 \$ 1$ k.k., a art. $297 \$ 1$ k.k. Zestawienie tej części znamion strony przedmiotowej wskazuje na to, że art. $286 \$ 1$ k.k. ma szerszy zakres zastosowania, albowiem nie przewiduje ograniczeń co do sposobów na wprowadzenie konkretnego podmiotu w błąd, w przeciwieństwie do art. $297 \$ 1$ k.k.

12 Nie ulega wątpliwości, że takie działanie będzie również realizować znamiona przestępstwa $\mathrm{z}$ art. $297 \$ 1$ k.k., gdyż zobowiązanie co do wykorzystania udzielonego wsparcia na określony cel będzie pisemnym oświadczeniem dotyczącym okoliczności o istotnym znaczeniu. 
Kolejnym elementem różnicującym jest czas popełnienia czynu zabronionego. Tak jak już wcześniej wskazano, przestępstwo z art. $297 \$ 1$ k.k. jest przestępstwem formalnym. Dlatego też sprawca popełnia ten występek już w momencie, gdy przedkłada dokumenty, które np. poświadczają nieprawdę ${ }^{13}$. Nie jest zatem konieczne, aby organ dysponujący funduszami unijnymi został skutecznie przez sprawcę wprowadzony w błąd. Dlatego też dla bytu omawianego występku nie ma znaczenia okoliczność, czy sprawca otrzymał wypłatę konkretnej sumy pieniężnej. Pod wątpliwość należy zatem poddać stanowisko R. Zawłockiego, zdaniem którego do momentu rozpoznania wniosku o przyznanie dotacji unijnej zachowanie znajduje się na etapie usiłowania ${ }^{14}$. Przede wszystkim wskazany pogląd pozostaje w sprzeczności wobec ustalenia, że samo przedłożenie wniosku jest równoznaczne $z$ wypełnieniem znamion strony przedmiotowej występku z art. $297 \$ 1$ k.k. Zaznaczyć należy, że przedłożenie dokumentacji to element, który odnosi się do zachowania sprawcy, a nie podmiotu udzielającego dotację. Dokumentacja jest przedłożona z chwilą wpływu do organu dysponującego środkami unijnymi i ten moment jest równoznaczny z popełnieniem tego występku.

Z kolei podniesione powyżej okoliczności będą mieć znaczenie na gruncie art. $286 \$ 1$ k.k. Nie ulega bowiem wątpliwości, że oszustwo jest popełnione $\mathrm{z}$ chwilą doprowadzenia pokrzywdzonego do niekorzystnego rozporządzenia mieniem. W sytuacji, gdy sprawcy nie udało się uzyskać wsparcia unijnego pomimo takiego zamiaru, to wówczas doszło do usiłowania popełnienia przestępstwa oszustwa i dokonania występku objętego dyspozycją art. $297 \$ 1 \mathrm{k} . \mathrm{k}$. Analizowany element nie pozostaje zatem bez znaczenia dla kwalifikacji prawnej czynu. W takim przypadku sprawca swoim czynem zrealizował znamiona określone w dwóch przepisach ustawy karnej, tj. art. $297 \$ 1$ k.k. w zb. z art. 13 $\$ 1$ k.k. w zw. z art. $286 \$ 1$ k.k. w zw. z art. $11 \S 2$ k.k.

13 Wyrok SA w Warszawie z 28 listopada 2014 r., sygn. akt II AKa 356/14, «Lex» nr 1563692; M. Bojarski, [w:] Kodeks karny. Komentarz, red. M. Filar, Warszawa 2016, s. 1587.

14 R. Zawıocki, [w:] Kodeks karny. Część szczególna. Komentarz do artykułów 222-316, red. A. WĄsek, R. ZaWŁocki, Warszawa 2010, s. 1387. 
Z tego powodu krytyce należy poddać stanowisko wyrażone w wyroku SA w Warszawie z 24 czerwca 2013 r., w myśl którego „przepis art. 297 służy do kryminalizacji zachowań na przedpolu naruszenia dóbr prawnych chronionych przez art. 286. Jest, co więcej, przestępstwem o charakterze formalnym, dla jego realizacji nie jest konieczne wystąpienie skutku w postaci uzyskania kredytu, a tym samym zaistnienia szkody majątkowej"15. Stanowisko wyrażone w tym judykacie jest błędne. Jeżeli dysponent środków pieniężnych dostrzeże, że wnioskodawca zamierza wprowadzić go w błąd co do chociażby zamiaru wykorzystania dotacji na ściśle wskazany cel, to tym samym sprawca powinien ponieść odpowiedzialność karną również za usiłowanie oszustwa (art. $13 \$ 1$ k.k. w zw. art. $286 \$ 1$ k.k.). Z całą pewnością obecne ukształtowanie art. $297 \S 1$ k.k. nie pozwala przyjąć, że tylko na podstawie tego przepisu powinien odpowiadać sprawca, który dążył do bezprawnego uzyskania dotacji. W takim przypadku niezastosowanie konstrukcji kumulatywnej kwalifikacji prawnej czynu stanowiłoby obrazę prawa materialnego poprzez niewłaściwe niezastosowanie art. $13 \$ 1$ k.k. w zw. $z$ art. $286 \$ 1$ k.k.

Z powyższych rozważań wynika, że pomiędzy art. $286 \$ 1$ k.k. i art. $297 \S 1$ k.k. reguła specjalności nie znajduje zastosowania. Na brak takiej możliwości wskazuje to, że przestępstwo z art. $297 \$ 1$ k.k. jest dokonane, w odróżnieniu do art. $286 \$ 1$ k.k., niezależnie od tego, czy nastąpił fakt wypłaty nienależnej dotacji. Ponadto art. $297 \$ 1$ k.k. przewiduje ograniczony katalog czynności, przy pomocy których sprawca chce uzyskać unijne wsparcie, co eliminuje możliwość zastosowania tej reguły wyłączania wielości ocen ${ }^{16}$.

Bardziej problematyczna wydaje się jednak kwestia wzajemnej relacji art. $286 \$ 1$ k.k. i art. $297 \$ 1$ k.k. w przypadku, gdy podmiot wnioskujący o udzielenie wsparcia unijnego w postaci dotacji chce zrealizować dany projekt, jednak przedkłada podrobione dokumenty, co do pewnych okoliczności mających znaczenie dla możliwości skorzystania z określonego

15 Wyrok SA w Warszawie z 24 czerwca 2013 r., sygn. akt II Aka 188/13, «Lex» nr 1342397.

16 Wyrok SA we Wrocławiu z 23 maja 2014 r., sygn. akt II AKa 63/13, «Lex» nr 1356738; D. JagieŁŁo, Oszustwa przetargowe «Zamówienia Publiczne Doradca» 9/2008, s. 76. 
programu unijnego (np. wnioskodawca przedstawia fałszywą dokumentację co do wcześniej zakończonych inwestycji, posiadanego doświadczenia). Jak już wcześniej wskazano, występek z art. $297 \$ 1$ k.k. ma charakter formalny i dlatego w tym przypadku sprawca popełnił czyn stypizowany w tym przepisie. Dla bytu tego przestępstwa nie jest ważny skutek w postaci niekorzystnego rozporządzenia własnym lub cudzym mieniem. Powstaje jednak pytanie, czy takie działanie sprawcy wypełniło również znamiona przestępstwa oszustwa. Wątpliwości w tym zakresie wynikają z tego, że sprawca ma zamiar wydatkować uzyskane środki zgodnie $\mathrm{z}$ ich przeznaczeniem. Kluczowym dla rozstrzygnięcia tego problemu jest określenie, czy takie zachowanie może doprowadzić dysponenta funduszy unijnych do niekorzystnego rozporządzenia mieniem, albowiem realizacja pozostałych znamion strony przedmiotowej nie budzi wątpliwości. Podkreślić bowiem należy, że cel w postaci realizacji określonego przedsięwzięcia (np. przeprowadzenia szkolenia) został zrealizowany, a kwota udzielonego wsparcia została rozliczona. Z tego wynika, że organ udzielający dotacji nie poniósł rzeczywistej szkody majątkowej. Wskazane okoliczności pozostają jednak irrelewantne z punktu widzenia realizacji znamion czynu zabronionego z art. 286 $\$ 1$ k.k. O niekorzystności rozporządzenia mieniem decyduje subiektywny element rozumiany w ten sposób, że pokrzywdzony nie udzieliłby wsparcia unijnego, gdyby wiedział o tym, że dokumentacja przedłożona przez wnioskodawcę jest podrobiona ${ }^{17}$. Poza tym udzielenie dotacji podmiotowi, który nie dawał rękojmi właściwej realizacji określonego zadania było $a b$ initio niekorzystne. Ustalenie wyżej wskazanych faktów będzie rzutować jedynie na wymiar kary (art. $53 \$ 1$ k.k.), albowiem sąd powinien wziąć pod uwagę zachowanie sprawcy po popełnieniu przestępstwa oraz motywację, którą się kierował.

Z powyższego wynika zatem, że również w tym przypadku sprawca zrealizował znamiona dwóch występków z art. $297 \$ 1$ k.k. oraz art. 286 $\$ 1$ k.k. To z kolei pociąga za sobą konieczność zastosowania instytucji kumulatywnej kwalifikacji prawnej czynu.

17 Wyrok SN z 2 października 2015 r., sygn. akt III KK 148/15, «Lex» nr 1816561. 
Rozważania dotyczące problematyki art. $286 \$ 1 \mathrm{k} . \mathrm{k}$. należy jeszcze uzupełnić o możliwość zastosowania tego przepisu w razie wykorzystania dotacji niezgodnie z jej przeznaczeniem. Jak już wcześniej wspomniano, zachowanie polegające na przeznaczeniu dotacji na inny cel wyczerpuje znamiona występku skarbowego objętego dyspozycją art. $82 \$ 1$ k.k.s. Powstaje jednak pytanie, czy taki czyn może zostać również zakwalifikowany jako oszustwo. Wydaje się, że elementem decydującym o konieczności zastosowania konstrukcji idealnego zbiegu przestępstwa i przestępstwa skarbowego jest moment powzięcia zamiaru wykorzystania dotacji niezgodnie z jej przeznaczeniem. Jeżeli taki zamiar towarzyszył sprawcy jeszcze przed uzyskaniem wsparcia unijnego, to w takim wypadku zrealizował on również znamiona występku $\mathrm{z}$ art. $286 \$ 1 \mathrm{k} . \mathrm{k}$. Takie twierdzenie wynika z tego, że wprowadzenie w błąd może dotyczyć faktycznej realizacji konkretnego zadania lub przedsięwzięcia. Z punktu widzenia znamion strony przedmiotowej nie ma bowiem znaczenia to, czy sprawca przeznaczył uzyskane środki na inny cel. Przede wszystkim sprawca działał w celu osiągnięcia korzyści majątkowej, ponieważ realizacja zadania współfinansowanego ze środków unijnych zakładała uzyskanie określonej dotacji. Ponadto doprowadził organ dysponujący środkami unijnymi do niekorzystnego rozporządzenia mieniem, albowiem udzielone wsparcie nie zostało wydatkowane na zakładany cel. Wreszcie sprawca wprowadził pracownika podmiotu udzielającego dotację, co do faktycznej realizacji określonego zadania.

Inaczej jednak należy zakwalifikować zachowanie sprawcy, który powziął zamiar przeznaczenia dotacji niezgodnie z jej celem dopiero w trakcie realizacji konkretnego zadania. W takim przypadku czyn sprawcy nie realizuje znamion przestępstwa oszustwa. Podkreślić należy, że sprawca działa z góry powziętym zamiarem wówczas, gdy występując o udzielenie dotacji chce ją przeznaczyć na inny cel. Innymi słowy, ustalenia dotyczące strony podmiotowej przekreślają możliwość przyjęcia działania z góry powziętym zamiarem. Dlatego też analizowane zachowanie podlega penalizacji na podstawie art. $82 \$ 1$ k.k.s. 


\section{Podsumowanie}

Z powyższych rozważań wynika jednoznacznie, że w zdecydowanej większości przypadków powinno dojść do zbiegu idealnego czynu objętego dyspozycją art. $286 \$ 1$ k.k. w zb. z art. $297 \$ 1$ k.k. w zw. z art. 11 $\$ 2$ k.k i art. $82 \$ 1$ k.k.s. Istnieje jednak pewien obszar zachowań, który będzie realizować wyłącznie znamiona występku skarbowego bądź przestępstwa oszustwa. W związku z powyższym propozycja uchylenia art. $82 \$ 1$ k.k.s. budzi pewne wątpliwości. Wydawać by się mogło, że rozbudowana regulacja w zakresie środków prowadzących sprawcę do wyłudzenia dotacji jest na tyle szeroka, że właściwie obejmuje swoim zakresem wszystkie sposoby działania sprawców mających na celu pozyskanie środków unijnych. Problem polega jednak na tym, że art. $297 \$ 1 \mathrm{k} . \mathrm{k}$. nie obejmuje penalizacją zachowania polegającego na wykorzystaniu dotacji niezgodnie z jej przeznaczeniem. Co więcej, w razie braku możliwości udowodnienia sprawcy, że już w momencie, gdy występował o przyznanie dotacji, miał zamiar przeznaczyć wsparcie unijne na inny cel, nie można mu przypisać odpowiedzialności za występek z art. $286 \$ 1$ k.k.

Wydaje się również, że poprzestanie na uznaniu takiego zachowania za rodzącego jedynie odpowiedzialność cywilnoprawną nie byłoby wystarczającym instrumentem ostrzegającym beneficjentów przed niezgodnym z przeznaczeniem wykorzystaniu dotacji. Trzeba mieć bowiem na względzie to, że wsparcie pochodzące ze środków unijnych przedstawia z reguły wysoką wartość. Nie można wreszcie zapominać o tym, że dotacja jest wypłacana ze środków budżetu państwa.

Z kolei szerokie, aczkolwiek enumeratywne wymienienie cech, jakim musi odpowiadać dokumentacja przedłożona przez ubiegającego się o uzyskanie dotacji, wpływa na to, że niektóre zabiegi, które mają wywołać mylne wyobrażenie co do rzeczywistego wykorzystania dotacji realizują jedynie znamiona przestępstwa oszustwa. $Z$ uwagi na to, że etap bezpośredniego zmierzania do bezprawnego uzyskania dotacji jest objęty przez konstrukcję usiłowania oszustwa, to tym samym ewentualne wyeliminowanie dotacji z katalogu instrumentów finansowych 
podlegających ochronie na podstawie art. $297 \$ 1 \mathrm{k} . \mathrm{k}$. nie wpłynie na zawężenie zakresu odpowiedzialności za takie działania.

PRAWNOKARNE ASPEKTY WYŁUdZENIA DOTACJI UNII EUROPEJSKIEJ

\section{Streszczenie}

Artykuł podejmuje problematykę wyłudzenia dotacji z Unii Europejskiej jako istotnego rodzaju działalności tzw. „białych kołnierzyków”. Akcesja Polski do Unii Europejskiej, która miała miejsce w maju 2004 roku, spowodowała, że grupy przestępcze zyskały nowy obszar dla swojej działalności w postaci możliwości wyłudzania dotacji na szkodę interesów finansowych tej organizacji. Artykuł stanowi krytyczną analizę obecnych uregulowań dotyczących bezprawnego uzyskania wsparcia finansowego z UE. Głównym problem jest kwestia kwalifikacji prawnej czynu polegającego na wyłudzeniu dotacji. Stwierdzić należy, że do omawianej problematyki nawiązuje art. $286 \$ 1$ k.k., art. $297 \$ 1$ k.k. oraz art. $82 \$ 1$ k.k.s. Autor wyjaśnił różnice oraz podobieństwa zachodzące między tymi przepisami. Analiza treści tych przepisów doprowadziła do wniosku, że obecna stylizacja norm Kodeksu karnego wymaga zmiany. W ocenie autora, dotacja powinna zostać wyłączona z katalogu instrumentów finansowych chronionych w art. $297 \$ 1$ k.k.

\section{Criminal Law Aspects of Fraudulent grants of European UNION FUNDS}

\section{Summary}

The article discusses the fraudulent award of EU grants as a white collar crime. Poland joined the European Union in May 2004, opening up the door for new criminal groups to commit financial offences against the interest of the EU. This paper presents a critical analysis of the Polish provisions on EU grants. The first major problem he discusses is the legal qualification of the offence under Polish law. An offender may be charged under several articles of the Polish Criminal Code (286 
$\$ 1,297 \$ 1$, or $82 \$ 1$ of the Fiscal Criminal Code.) The author explains the differences and similarities between these provisions. He concludes that the current provisions require amendment, in particular he argues that Article $297 \$ 1$ of the Polish Criminal Code should not be used as an instrument for financial protection against EU fraud.

Słowa kluczowe: odpowiedzialność karna; dotacja; wyłudzenie; przestępczość „białych kołnierzyków”; szkoda finansowa.

Keywords: criminal liability; grant, fraudulent; white collar crime; financial detriment.

\section{Literatura}

Bojarski M., [w:] Kodeks karny. Komentarz, red. Filar M., Warszawa 2016 GaŁązKa M., [w:] Kodeks karny. Komentarz, red. GrześKowiak A., Wiak K., Warszawa 2017

Grzegorczy K T., Kodeks karny skarbowy. Komentarz, Warszawa 2009

JagieŁŁo D., Oszustwa przetargowe, «Zamówienia Publiczne Doradca» 9/2008 Komunikat Prokuratury Generalnej, por. http://pk.gov.pl/aktualnosci-prokuratury-krajowej/prokuratura-generalna-o-przestepstwach-na-szkode-finansowych-interesow-unii-europejskiej-2-693,subakcja,print.html, dostęp 10 stycznia 2017 r.)

Kotowski W., KurzęPA B., Kodeks karny skarbowy. Komentarz, Warszawa 2006

ŁabudA G., [w:] Kodeks karny skarbowy. Komentarz, red. Kardas P., ŁabUdA G., Razowski T., Warszawa 2012

Michalska-Warias A., [w:] Kodeks karny. Część szczególna, II, red. KRóliKowsкi M., ZawŁocki R., Warszawa 2013

Piaseczny A., Kodeks karny skarbowy. Komentarz, «Legalis»

WiLK L., Zasada priorytetu egzekucji nad represja w prawie karnym skarbowym, «Prokuratura i Prawo» 7-8/2012

ZAwŁocki R., [w:] Kodeks karny. Część szczególna. Komentarz do artykułów 222-316, red. WĄSEK A., ZawıOCKI R., Warszawa 2010

Zgoliński I., [w:] Kodeks karny. Komentarz, red. V. Konarska-Wrzosek, Warszawa 2016

ŻóŁTeK S., Szkoda i pokrzywdzony przestępstwem oszustwa kredytowego, «Monitor Prawniczy» 21/2011. 